\title{
MODEL INKUIRI TERBIMBING BERBANTUAN MULTIMEDIA INTERAKTIF UNTUK MENINGKATKAN PENGUASAAN KONSEP FISIKA PESERTA DIDIK
}

\author{
Syahriani Yulianci, Gunawan, Aris Doyan \\ Program Studi Magister Pendidikan IPA \\ Program Pascasarjana, Universitas Mataram \\ Jalan Majapahit No. 62, Mataram \\ E-Mail: syahriani.yulianci@unram.ac.id
}

\begin{abstract}
The purpose of this study is to examine the effectiveness of learning use the guided inquiry model with interactive multimedia toward mastery of concept physics students. The study involved 68 students who were divided into two groups, the experimental group and control group. The research instrument used a mastery of concept physics students. Data were analyzed by using normalized gain scores. The result showed an increase in mastery of concept physics in both groups but experimental have the high increase more than control group. The result indicate that the guided inquiry learning with interactive multimedia is effective in enhancing mastery of concept physics students.
\end{abstract}

Keywords: guided inquiry model, interactive multimedia, mastery of concept physics

\section{PENDAHULUAN}

Belajar fisika pada jenjang SMA bertujuan agar peserta didik mampu menguasai konsep-konsep fisika dan saling keterakitannya, serta mampu menggunakan metode ilmiah berlandaskan sikap ilmiah untuk memecahkan masalah-masalah yang dihadapinya (Mundilarto, 2002). Sehingga dalam belajar Fisika peserta didik dibekali sejumlah pemahaman dan kemampuan yang diprasyaratkan untuk memasuki jenjang pendidikan yang lebih tinggi serta mengembangkan ilmu pengetahuan dan teknologi. Oleh karena itu mata pelajaran fisika dianggap penting diajarkan pada sekolah menengah.

Fisika merupakan ilmu yang berkarakteristik kompleks, rumit, dan berkaitan erat dengan kehidupan nyata. Kajian ilmu Fisika juga berhubungan dengan struktur penyusun materi yang dideskripsikan secara kualitatif (bagaimana) dan kuantitatif (berapa, berupa persamaan), mulai dari materi skala yang paling besar (makro) hingga skala yang paling kecil (Jati, 2007). Oleh karena itu, dengan sifatnya yang sangat kompleks, fisika sering dianggap sebagai pelajaran yang sulit dipahami karena penerapan rumus-rumus ke dalam soal bukanlah hal yang mudah (Sirait, 2012).

Samudra (2014) juga mengungkapkan kesulitan peserta didik dalam mempelajari Fisika disebabkan oleh materi Fisika yang padat dan tidak kontekstual. Konsekuensinya adalah banyak peserta didik yang mencoba menghafalkan konsep-konsep dan rumusrumus Fisika tanpa mendalami makna fisisnya (Hammer, 1994). Peserta didik hanya mampu menggunakan rumus-rumus dalam Fisika untuk mendapatkan hasil namun tidak dapat memahami makna di balik penggunaan rumus tersebut. Akibatnya, mereka tidak memiliki pemahaman materi Fisika yang baik. Hal tersebut kemudian berdampak pada penguasaan konsep Fisika.

Anderson \& Krathwol (2001) menyatakan bahwa konsep merupakan jenis pengetahuan yang tersusun atas keterkaitan antara unsur-unsur dasar sehingga terbentuk struktur yang lebih besar yang memungkinkan 
mereka untuk berfungsi bersama-sama. Konsep merupakan dasar bagi proses mental yang lebih tinggi untuk merumuskan prinsip dan generalisasi.

Pembelajaran berdasarkan metode ilmiah dapat mengembangkan penalaran dan keterampilan ilmiah peserta didik (Wenning, 2011). Salah satu model pembelajaran yang yang didasarkan metode ilmiah adalah model inkuiri terbimbing. Melalui model pembelajaran ini peserta didik dihadapkan pada aktivitas ilmiah, seperti terampil dalam mengamati, mengukur, mengklasifikasi, menarik kesimpulan, dan mengkomunikasikan temuan, sehingga dapat disimpulkan bahwa model pembelajaran inkuiri dapat meningkatkan hasil belajar peserta didik (Lederman \& Antink, 2010).

Seiring dengan perkembangan Ilmu Pengetahuan dan Teknologi (IPTEK) yang begitu pesat, maka selain model pembelajaran yang berinovasi, perlu ada juga inovasi pada media pembelajaran, baik itu media riil ataupun media abstrak. Menurut Finkelstein et. al., (2005), bahwa komputer dapat digunakan untuk menunjang pelaksanaan praktikum fisika, sehingga komputer dapat digunakan dalam proses pembelajaran fisika. Salah satu bentuk pemanfaatan teknologi komputer dalam pembelajaran fisika adalah penggunaan multimedia interaktif.

Penggunaan media dalam proses pembelajaran tidak dapat berdiri sendiri karena media hanya digunakan sebagai alat bantu, sehingga media pembelajaran harus diiringi dengan suatu model yang tepat. Dalam penelitian ini akan digunakan model inkuiri terbimbing berbantuan multimedia interaktif. Beberapa penelitian tentang pengaruh dari kolaborasi model pembelajaran dan multimedia interaktif, di antaranya Wahyudin (2010), yang menemukan bahwa penerapan metode pembelajaran inkuiri terbimbing dengan berbantuan multimedia dapat meningkatkan minat dan pemahaman peserta didik, Husein (2015) yang menunjukkan bahwa multimedia interaktif dalam pembelajaran fisika berpengaruh pada penguasaan konsep fisika peserta didik, serta Gunawan (2013, 2016) menemukan bahwa model virtual laboratory fisika dapat meningkatkan penguasaan konsep mahasiswa dan meningkatkan keterampilan generik sains calon guru.

\section{METODE PENELITIAN}

Jenis penelitian adalah kuasi eksperimen dengan tujuan untuk menguji pengaruh perlakuan tertentu terhadap variabel-variabel yang diteliti serta dalam kondisi yang dikendalikan. Dalam penelitian ini model inkuiri terbimbing berbantuan multimedia interaktif merupakan variabel bebas, dan penguasaan konsep fisika merupakan variabel terikat.

Penelitian dilaksanakan di SMAN 5 Mataram tahun ajaran 2017/2018. Populasi penelitian adalah seluruh peserta didik kelas $\mathrm{X}$ MIPA SMAN 5 Mataram berjumlah 187 peserta didik. Teknik pengambilan sampel menggunakan cluster random sampling. Sampel sebanyak 2 kelas yakni kelas X MIPA 1 berjumlah 33 siswa sebagai kelas kontrol dan kelas X MIPA 2 berjumlah 35 siswa sebagai kelas eksperimen.

Penelitian ini menggunakan pretestposttest control group design. Kelas eksperimen melakukan pembelajaran dengan menggunakan model inkuiri terbimbing berbantuan multimedia interaktif, sedangkan kelas kontrol melakukan pembelajaran secara konvensional. Data penguasaan konsep fisika, diperoleh sebelum dan sesudah perlakuan. Tes penguasaan konsep diberikan diawal dengan alasan untuk melihat kemampuan awal peserta didik, dan diberikan diakhir untuk melihat seberapa besar peningkatan penguasaan konsep mereka. 
Pengumpulan data penguasaan konsep menggunakan instrumen penguasaan konsep fisika yang berbentuk pilihan ganda sebanyak 22 soal dengan lima alternatif pilihan jawaban. Penguasaan konsep fisika yang dimaksud adalah konsep-konsep pada materi besaran fisika dan pengukuran. Sub materi yang akan diteliti adalah besaran dan satuan, besaran pokok dan besaran turunan, dimensi satuan, notasi ilmiah, angka penting, pengukuran.

Penyusunan instrumen penguasaan konsep tersebut mengikuti ranah kognitif yang sesuai dengan taksonomi Bloom revisi Andersoon, yaitu dari ranah kognitif $\mathrm{C} 1$ (mengingat), $\quad \mathrm{C} 2 \quad$ (memahami), $\quad \mathrm{C} 3$ (menerapkan), $\mathrm{C} 4 \quad$ (menganalisis), $\mathrm{C5}$ (menilai), dan C6 (menciptakan). Sehingga dalam penelitian ini akan dibahas dua data penguasaan konsep peserta didik yaitu berdasarkan tiap sub materi, dan berdasarkan tingkatan ranah kognitif.

Data dianalisis menggunakan uji skor $\mathrm{N}$ gain yang dilakukan untuk mengetahui seberapa besar peningkatan penguasaan konsep peserta didik setelah diberi perlakuan. Kesimpulan hasil interpretasi data disesuaikan dengan kriteria seperti pada Tabel 1.

Tabel 1. Interpretasi Skor N-gain

\begin{tabular}{lc}
\hline \multicolumn{1}{c}{ Persentase } & Kategori \\
\hline$N$-gain $>0,70$ & Tinggi \\
$0,70>N$-gain $\geq 0,30$ & Sedang \\
$N$-gain $<0,30$ & Rendah \\
\hline
\end{tabular}

(Sumber : Hake, 1999)

\section{HASIL DAN PEMBAHASAN}

Berdasarkan analisis data, nilai penguasaan konsep peserta didik memiliki peningkatan yang cukup tinggi, ini terlihat dari perbedaan nilai tes awal dan tes akhir yang diperoleh kelas eksperimen maupun kelas kontrol. Perbandingan rata-rata tes awal, tes akhir, serta persentase $\mathrm{N}$-gain penguasaan konsep fisika kelas eksperimen dan kelas kontrol dapat dilihat pada Tabel 2.
Nilai rata-rata tes awal pada kelas eksperimen dan kelas kontrol terlihat kelas kontrol lebih unggul dengan selisih 9,33. Hasil uji beda rerata pada data tes awal diperoleh nilai $t_{\text {hitung }}$ sebesar 1,33 dan $t_{\text {tabel }}$ sebesar 1,77 pada taraf signifikansi 0,05 . Sehingga dari hasil tersebut dapat disimpulkan bahwa penguasaan konsep kelas eksperimen dan kelas kontrol sebelum pembelajaran tidak berbeda secara signifikan.

Selanjutnya berdasarkan perolehan nilai tes akhir kedua kelas, terlihat bahwa kelas eksperimen memperoleh nilai 92,12 sedangkan kelas kontrol 86,67. Kedua kelas terlihat sama sama mengalami peningkatan, namun kelas eksperimen memiliki peningkatan yang relatif tinggi dibandingkan kelas kontrol. Hal ini dibuktikan dari persentase $\mathrm{N}$-gain yang diperoleh kelas eksperimen sebesar $83,54 \%$ dengan kriteria tinggi dan kelas kontrol $64,42 \%$ dengan kriteria sedang. Perolehan data tersebut menunjukkan bahwa penguasaan konsep fisika pada kelas yang melakukan pembelajaran menggunakan model inkuiri terbimbing berbantuan multimedia interaktif lebih baik dibandingkan dengan kelas yang tidak belajar dengan menggunakan model tersebut. Perbandingan rata-rata tes awal, tes akhir, dan persentase $\mathrm{N}$-gain pada kedua kelas ditampilkan pada Tabel 2.

Tabel 2. Perbandingan Rata-Rata Penguasaan Konsep Fisika Peserta Didik

\begin{tabular}{lcc}
\hline $\begin{array}{l}\text { Nilai rata- } \\
\text { rata }\end{array}$ & $\begin{array}{c}\text { Kelas } \\
\text { Eksperimen } \\
(\mathrm{N}=35)\end{array}$ & $\begin{array}{c}\text { Kelas Kontrol } \\
(\mathrm{N}=33)\end{array}$ \\
\hline Tes Awal & 52,12 & 61,45 \\
Tes Akhir & 92,12 & 86,67 \\
N-gain $(\%)$ & 83,54 & 64,42 \\
\hline
\end{tabular}

Peningkatan penguasaan konsep fisika kedua kelas dianalisis tiap sub materi sesuai dengan perolehan skor $\mathrm{N}$-gain yang disajikan pada Tabel 3. Berdasarkan Tabel 3. kelas eksperimen memperoleh peningkatan yang masksimal pada sub materi besaran pokok dan turunan yaitu sebesar 100,00\% dengan kategori 
tinggi. Sedangkan yang terendah adalah pada sub materi besaran dan satuan dengan skor $\mathrm{N}$ gain sebesar $60,00 \%$ dengan kategori sedang. Sedangkan pada kelas kontrol perolehan skor $\mathrm{N}$-gain tertinggi terjadi pada sub materi dimensi sebesar 82,09\% dengan kategori tinggi, sedangkan perolehan skor $\mathrm{N}$-gain terendah adalah pada sub materi besaran dan satuan dengan skor $47,37 \%$ dan termasuk pada kategori sedang.

Selisih peningkatan $\mathrm{N}$-gain tertinggi antara kelas eksperimen dan kelas kontrol diperoleh pada sub materi angka penting sebesar 34,49\%. Sedangkan selisih peningkatan skor $\mathrm{N}$-gain terendah terjadi pada sub materi dimensi yaitu sebesar 6,37\%. Pada Gambar 2. ditampilkan persentase perolehan penguasaan konsep fisika pada kelas eksperimen dan kelas kontrol berdasarkan sub materi. Hasil ini serupa dengan beberapa penelitian sebelumnya di antaranya oleh Kusdiastuti (2016) yang menunjukkan bahwa model pembelajaran inkuiri berbantuan lab virtual berpengaruh pada penguasaan konsep fisika siswa. Wahyudin (2010) yang menunjukkan bahwa penerapan metode pembelajaran inkuiri terbimbing dengan berbantuan multimedia dapat meningkatkan minat dan pemahaman siswa.
Selain itu Nisrina et. al., (2016) serta Hayati (2017) yang menunjukkan bahwa penggunaan model inkuiri terbimbing berbantuan media yang berbasis ICT seperti multimedia interaktif atau simulasi PheT dapat memberikan pengaruh pada penguasaan konsep fisika.

Namun tidak sejalan dengan penelitian oleh Retnosari (2016) yang menyimpulkan bahwa penggunaan model inkuiri terbimbing berbantuan multimedia interaktif tidak memberikan pengaruh yang signifikan pada keterampilan berpikir kritis yang imbasnya kepada peningkatan penguasaan konsep fisika peserta didik.

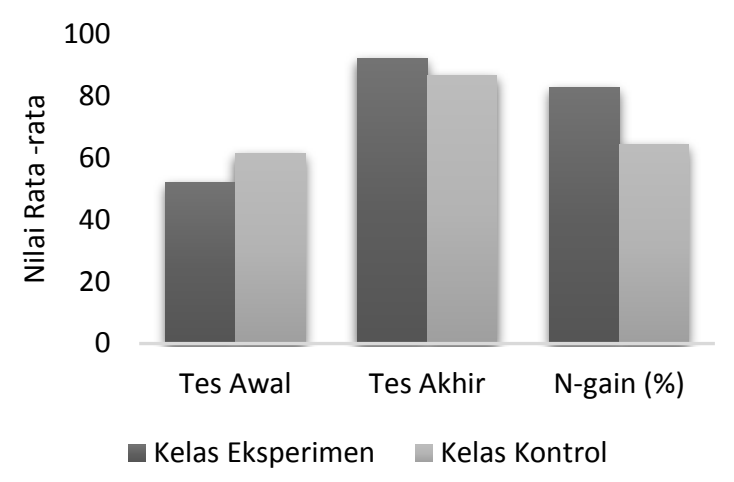

Gambar 1. Perbandingan Nilai Rata-Rata Penguasaan Konsep Peserta Didik

Tabel 3. Rekapitulasi Skor Penguasaan Konsep Fisika Tiap Sub Materi

\begin{tabular}{lccc}
\hline \multirow{2}{*}{ Sub Materi } & \multicolumn{2}{c}{ Persentase skor N-gain } & \multirow{2}{*}{$\Delta\langle g\rangle$} \\
\cline { 2 - 3 } & Kelas Eksperimen & Kelas Kontrol & \\
\hline PK 1 : Besaran dan satuan & 60,00 & 47,37 & 12,63 \\
PK 2 : Besaran Pokok dan Turunan & 100,00 & 71,43 & 28,57 \\
PK 3 : Dimensi & 88,46 & 82,09 & 6,37 \\
PK 4 : Notasi Ilmiah & 78,18 & 68,00 & 10,18 \\
PK 5 : Angka Penting & 91,43 & 56,94 & 34,49 \\
PK 6 : Pengukuran & 80,95 & 66,67 & 14,28 \\
\hline
\end{tabular}




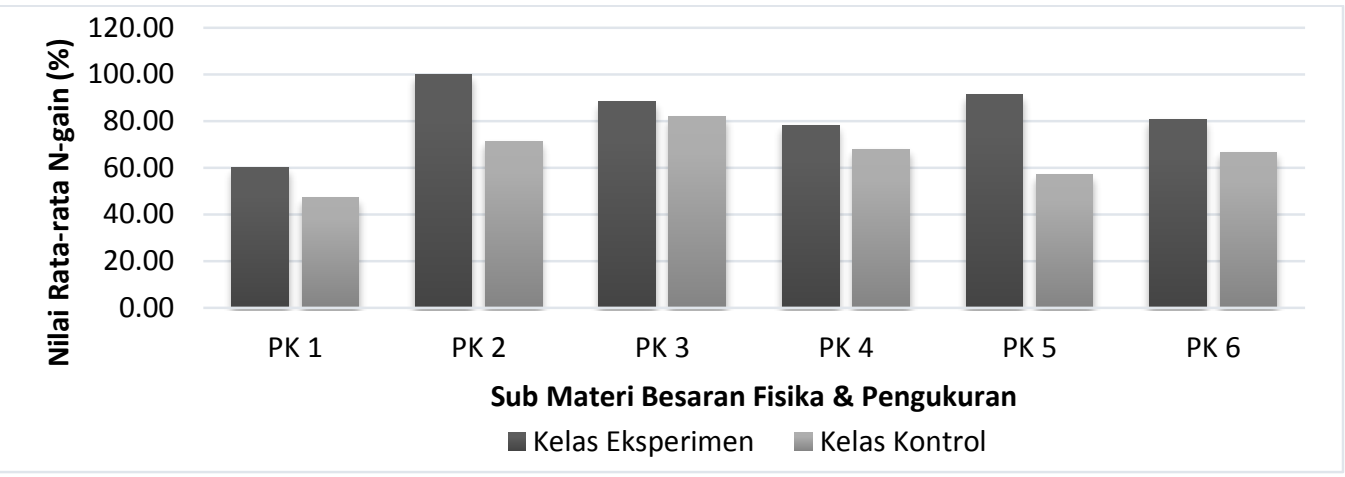

Gambar 2. Perbandingan Persentase N-gain Penguasaan Konsep Fisika untuk Tiap Sub Materi Besaran Fisika dan Pengukuran

Berdasarkan Gambar 2. terlihat bahwa pada sub materi dimensi (PK3) dan notasi ilmiah (PK4) kedua kelas, baik itu pada kelas eksperimen ataupun kelas kontrol memiliki perbedaan peningkatan yang tidak berbeda jauh. Hal ini disebabkan karena saat penyampaian materi pada kedua kelas dilakukan dengan cara yang sama di mana kedua kelas sama-sama diberikan contoh oleh guru untuk menyelesaikan permasalahan terkait sub materi dimensi dan notasi ilmiah. Karena memang pada awalnya peserta didik merasa kebingungan dengan istilah baru tersebut yang sebelumnya belum pernah mereka temukan.

Sub materi besaran pokok dan turunan pada kelas eksperimen memperoleh nilai peningkatan yang maksimal. Hal ini disebakan karena di awal pembelajaran guru menampilkan informasi terkait materi tersebut pada tampilan multimedia interaktif, dan LKPD yang mereka isi mengharuskan mereka memberikan contoh kalimat yang mereka buat sendiri terkait besaran pokok dan turunan yang tujuannya untuk mengetahui mereka sudah dapat membandingkan antara besaran pokok dan besaran turunan. Sehingga pada materi ini peserta didik dapat lebih mengingat apa yang mereka tulis dari pikiran mereka. Selain itu pada materi besaran pokok dan turunan, instrumen yang diberikan hanya berupa hafalan sehingga dengan menghafal saja peserta didik dapat mengisi soal tersebut. Sehingga tidak menutup kemungkinan peserta didik akan mendapatkan nilai yang maksimal pada materi tersebut.

Berbeda halnya dengan materi besaran dan satuan, terdapat soal yang mereka harus analisis untuk menyetarakan satuan pada ruas kiri dan ruas kanan, karena mereka tidak terbiasa dengan soal yang menganalisis, sehingga mereka sulit untuk mengerjakan soal tersebut dan dampaknya akan terlihat pada perolehan nilai rata-rata $\mathrm{N}$-gain yang cukup rendah.

Selain itu sub materi angka penting (PK5) juga mendapatkan nilai yang hampir maksimal dan peningkatannya berbeda jauh antara kedua kelas tersebut di mana kelas eksperimen jauh lebih unggul 34,49\% dari kelas kontrol dan merupakan perbedaan peningkatan yang paling tinggi antara sub-sub materi lainnya. Hal ini disebabkan oleh pengajaran yang begitu detail pada kelas eksperimen. Peserta didik diberikan beberapa contoh pada tayangan multimedia interaktif, dan kemudian mengisi LKPD, di mana peserta didik harus memberikan contoh tiap-tiap aturan angka penting. Dengan memberikan contoh yang benar, maka peserta didik tersebut sudah dapat membandingkan tiap aturan-aturan dalam angka penting.

Berbeda halnya dengan pengajaran kelas kontrol, mereka mengisi permasalahan LKPD yang sama halnya dengan kelas eksperimen, namun dalam hal ini guru tidak memberikan 
informasi di awal terkait angka penting melalui tayangan multimedia, dan tidak memberikan contoh, hanya peserta didik sendiri yang mencari refrensi pada buku mata pelajaran fisika.

Walaupun kelas eksperimen memiliki peningkatan yang relatif lebih unggul dibandingkan kelas kontrol, namun tetap dapat dikatakan bahwa terjadi peningkatan pada kedua kelas tersebut. Sehingga dapat disimpulkan bahwa pembelajaran menggunakan model inkuiri terbimbing berbantuan multimedia interaktif dapat meningkatkan penguasaan konsep fisika lebih baik dari pada kelas kontrol yang diajarkan secara konvensional.

Peningkatan penguasaan konsep juga ditinjau berdasarkan tingkatan ranah kognitif yang hasilnya ditampilkan pada Gambar 3 . Pada Gambar 3, terlihat bahwa kelas eksperimen memiliki peningkatan tertinggi pada ranah kognitif menilai (C5) sebesar 92,31\%, sedangkan peningkatan terendah terjadi pada ranah kognitif mencipta (C6) sebesar 57,14\%. Selain C5, kemampuan menerapkan (C3) pada kelas eksperimen terlihat memiliki nilai peningkatan yang tidak berbeda jauh dengan C5 yaitu 91,09\%. Hal ini disebabkan karena butir-butir soal yang mewakili untuk C3 bersifat hitungan yang sederhana, seperti menetukan mana yang termasuk besaran, satuan, besaran pokok, maupun besaran turunan. Selain itu juga mereka menentukan hasil pengukuran dari alat ukur panjang, dan alat ukur massa. Sehingga dari soal yang diberikan tersebut, peserta didik tidak membutuhkan analisis tingkat tinggi untuk menyelesaikan permasalahan yang diberikan.
Berbeda halnya dengan kelas kontrol, peningkatan tertinggi terjadi pada ranah kognitif mengingat (C1) sebesar 92,31\%, sedangkan peningkatan terendah pada kelas kontrol sama halnya seperti yang dialami kelas eksperimen yaitu pada tingkatan ranah kognitif mencipta (C6) sebesar 44,44\%.

Peningkatan ranah kognitif C6 pada kelas eksperimen dan kelas kontrol menjadi peningkatan terendah yang dialami kedua kelas tersebut dibandingkan dengan tingkatantingkatan ranah kognitif lainnya. Hal ini mengindikasikan bahwa pada tingkatan tersebut yaitu mencipta tidak cocok diajarkan dengan menggunakan media virtual seperti multimedia interaktif, dan seharusnya dilakukan secara riil. Sehingga dapat dikatakan bahwa pembelajaran yang telah dilakukan dengan menggunakan model inkuiri terbimbing berbantuan multimedia interaktif lebih dapat meningkatkan kognitif produk dibandingkan kognitif proses.

Pada tingkatan ranah kognitif menganalisis (C4), selisih peningkatan antara kedua kelas tersebut tidak berbeda jauh dibandingkan pada tingkatan ranah kognitif lainnya yaitu sebesar $5,27 \%$. Hal ini disebabkan karena kemampuan menganalisis dalam penyelesaian masalah pada sub materi besaran pokok dan turunan, serta dimensi sangat dilatih oleh guru. Sehingga saat mereka mengisi instrumen yang berisikan sub materi tersebut mereka secara mudah dapat menyelesaikannya. Sehingga hasilnya nilai peningkatan baik itu pada kelas eksperimen maupun kelas kontrol tidak berbeda jauh, walaupun kelas eksperimen relatif memiliki nilai peningkatan yang lebih unggul. 


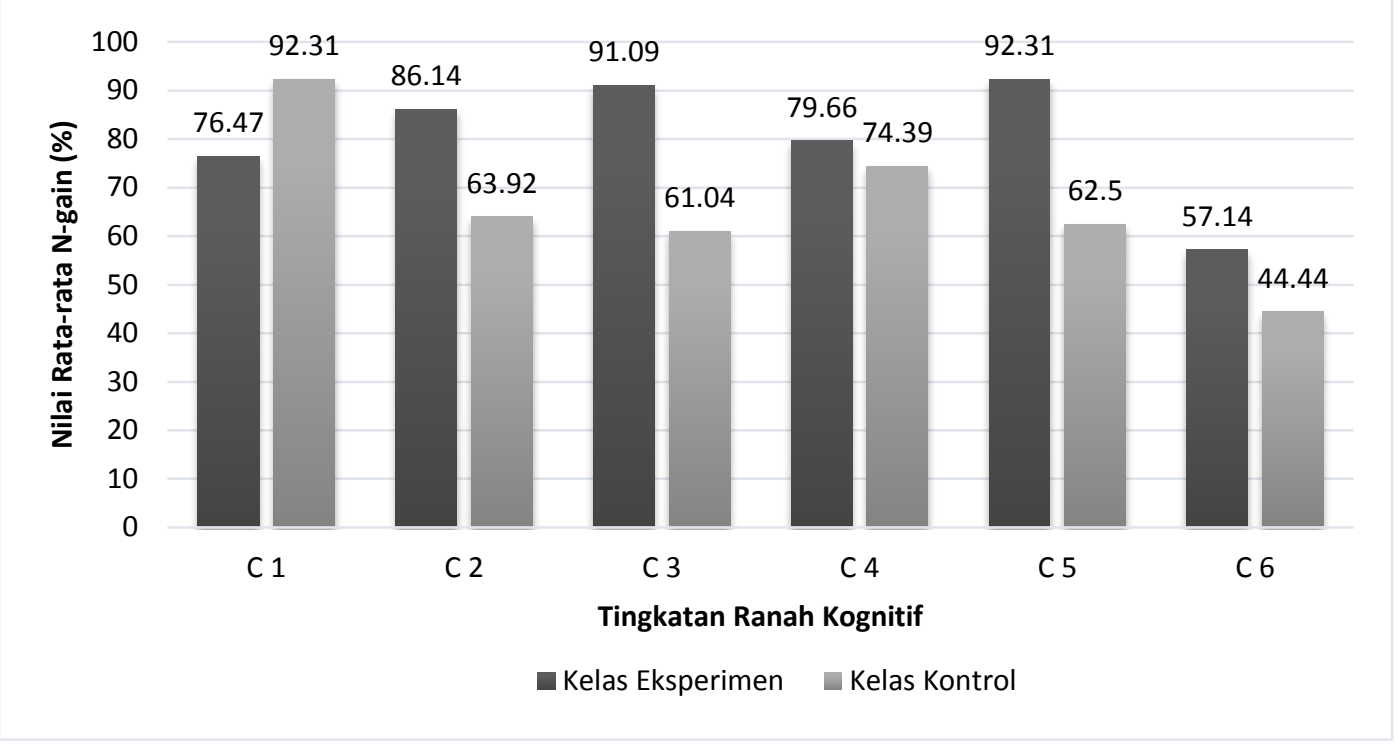

Gambar 3. Perbandingan Nilai Rata-rata N-gain Penguasaan Konsep Fisika Pada Tiap Tingkatan Ranah Kognitif Peserta Didik

Hal menarik dalam penelitian ini yang terlihat pada Gambar 3. bahwa tingkatan ranah kognitif mengingat $(\mathrm{C} 1)$ kelas kontrol jauh lebih unggul dibandingkan dengan kelas eksperimen dengan selisih sebesar $15,84 \%$. Hal ini menunjukkan bahwa untuk meningkatkan pada ranah kognitif tersebut dapat dilakukan hanya dengan pembelajaran konvensional, tidak membutuhkan model pembelajaran yang bervariasi. Hal ini sejalan dengan Simbolon \& Sahyar (2015) yang berpendapat bahwa tingkat kognitif $\mathrm{C} 1$ dan $\mathrm{C} 2$ tidak perlu menggunakan model yang bervariasi karena hanya membutuhkan tingkat pemahaman dan daya ingat saja.

Jika ditinjau dari model yang digunakan, hasil penelitian ini juga sejalan dengan pernyataan Hussain (2011) yang menyatakan bahwa model pembelajaran yang berorientasi pada penyelidikan ilmiah lebih baik dari pembelajaran konvensional. Senada dengan pernyataan tersebut, So \& Kong (2007) juga mengatakan bahwa meskipun ada peningkatan prestasi belajar yang signifikan pada kedua kelas, pengajaran dengan pendekatan yang berorientasi pada peserta didik dengan sedikit dikendalikan oleh guru melalui penggunaan komponen multimedia menghasilkan pencapaian yang lebih baik.

Hasil dari penelitian ini didukung penuh oleh beberapa penelitian sebelumnya di antaranya Evans \& Nicola (2006); Johnson \& Mayer (2009) yang menyatakan bahwa peserta didik yang belajar dengan multimedia interaktif memiliki hasil belajar yang lebih baik dibandingkan dengan kela yang tidak belajar menggunakan multimedia interaktif. Sehingga model inkuiri terbimbing berbantuan multimedia interaktif terbukti dapat meningkatkan penguasaan konsep fisika lebih baik dibandingkan dengan kelas yang melakukan pembelajaran secara konvensional.

\section{PENUTUP}

Berdasarkan hasil penelitian dapat disimpulkan bahwa penguasaan konsep fisika peserta didik dapat ditingkatkan melalui pembelajaran model inkuiri terbimbing berbantuan multimedia interaktif. Dalam penelitian ini sub materi besaran pokok dan turunan meningkat secara maksimal yaitu $100 \%$. Oleh karena itu peneliti menyarankan, dalam memberikan materi besaran fisika dan pengukuran, kegiatan praktikum seperti 
mengukur panjang ataupun massa, lebih baik dilakukan juga secara riil, sebab dengan menggunakan multimedia saja, peserta didik tidak mendapatkan pengalaman yang bermakna, sehingga kemampuan ranah kognitif seperti C6 dapat memberikan peningkatan yang cukup baik.

\section{REFERENSI}

Anderson, L.W., \& Krathwol, D.R, 2001. A Taxonomy for Learning, Teaching, and Assessing: A Revision of Bloom's Taxonomy of Educational Objectives. A Bridged Edition. New York: David McKey Company, Inc.

Evans, C., \& Gibbons, N. J. 2007. The interactivity effect in multimedia learning. Computers \& Education, 49(4), 1147-1160.

Finkelstein, et.al. 2005. When learning about the real world is better done virtually: A study of substituting computer simulations for laboratory equipment. Physics Education Research, 1(1), 1-8.

Gunawan., Setiawan, A., \& Widyantoro, D.W. 2013. Model Virtual Laboratory Fisika Modern untuk Meningkatkan Keterampilan Generik Sains Calon Guru. Jurnal Pendidikan dan Pembelajaran. 20(1), 25-32.

Gunawan, G., Harjono, A., \& Imran, I. 2016. Pengaruh Multimedia Interaktif dan Gaya Belajar Terhadap Penguasaan Konsep Kalor Siswa. Jurnal Pendidikan Fisika Indonesia. 12(2), 118-125.

Hake, R. 1999. Analyzing Change/Gain Score. Indiana: Indiana University.

Hammer, D. 1994. Epistemological Beliefs in Introductory Physics. Cognitive and Instruction. 12(2), 151-183.

Hayati, S.N., Hikmawati, H., Wahyudi W. 2017. Pengaruh Model Pembelajaran Inkuiri dengan Menggunakan Media Simulasi Terhadap Hasil Belajar Fisika Siswa Kelas X MIA SMAN 1 Lingsar
Lombok Barat Tahun Pelajaran 2016/2017. Jurnal Pendidikan Fisika dan Teknologi. 3(1), 48-54.

Husein, S., Herayanti, L., Gunawan, G. 2015. Pengaruh Penggunaan Multimedia Interaktif Terhadap Penguasaan Konsep dan Keterampilan Berpikir Kritis Siswa Pada Materi Suhu dan Kalor. Jurnal Pendidikan Fisika dan Teknologi. 1(3), 221-225.

Hussain, A., Azeem, M., \& Shakoor, A. 2011. Physics teaching methods: scientific inquiry vs traditional lecture. International Journal of Humanities and Social Science. 1(19), 269-276.

Jati, M.E. 2007. Fisika Dasar. Yogyakarta: Andi.

Kusdiastuti, M., Harjono, A., Sahidu, H., \& Gunawan. 2016. Pengaruh Model Pembelajaran Inkuiri Berbantuan Laboratorium Virtual Terhadap Penguasaan Konsep Fisika Peserta Didik. Jurnal Pendidikan Fisika dan Teknologi. 2 (3), 116-122.

Lederman, N. G., Lederman, J. S., \& Antink, A. 2013. Nature of science and scientific inquiry as contexts for the learning of science and achievement of scientific literacy. International Journal of Education in Mathematics, Science and Technology. 1(3) 137-147.

Mundilarto. 2002. Kapita Selekta Pendidikan Fisika. Yogyakarta: FMIPA UNY.

Nisrina, N., Gunawan, G., \& Harjono, A. 2016. Pembelajaran Kooperatif Dengan Media Virtual Untuk Peningkatan Penguasaan Konsep Fluida Statis Siswa. Jurnal Pendidikan Fisika dan Teknologi. 2(2), 66-72.

Retnosari, N. 2016. Pengaruh Model Inkuiri Terbimbing Berbantuan Multimedia Interaktif Terhadap Berpikir Kritis Siswa Kelas XI SMA Negeri di Bojonegoro. Jurnal Pendidikan. 1(8), 1529-1535.

Samudra, G. B., Suastra, I. W. \& Suma, K. 2014. Permasalahan-Permasalahan yang 
Dihadapi Siswa SMA di Kota Singaraja dalam Mempelajari Fisika. Jurnal Program Pascasarjana Universitas Pendidikan Ganesha Program Studi IPA. 4(1), 1-7.

Simbolon, D.H., \& Sahyar 2015. Pengaruh Model Pembelajaran Inkuiri Terbimbing Berbasis Eksperimen Riil dan Laboratorium Virtual Terhadap Hasil Belajar Fisika Siswa. Jurnal Pendidikan dan Kebudayaan. 21(3), 299-315.

Sirait, R. 2012. Pengaruh Model Pembelajaran Inquiry Training Terhadap Hasil Belajar Siswa Pada Materi Pokok Usaha Dan Energi Kelas VIII MTsN 3 Medan. Jurnal Pendidikan Fisika. 1(1), 21-26.

So, W.M.W., \& Kong, S. C. 2007. Approaches of inquiry learning with multimedia resources in primary classrooms. The Journal of Computers in Mathematics and Science Teaching, 26(4), 329-354.

Wahyudin. 2010. Keefektifan Pembelajaran Berbantuan Multimedia Menggunakan Metode Inkuiri Terbimbing Untuk Meningkatkan Minat dan Pemahaman Siswa. Jurnal Pendidikan Fisika Indonesia. 6(1), 58-62

Wenning, C.J. 2011. The Levels of Inquiry Model of Science Teaching. Journal of Physics Teacher Education Online. 6(2), 9-16. 